\title{
Transferul din limba maternă în învățarea limbilor străine, cauză a greșelilor din traduceri
}

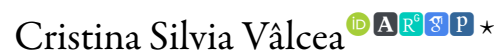 \\ Facultatea de Litere, Universitatea „Transilvania” din Brașov, Bd. Eroilor 29, 500036 Brașov, România
}

Despre articol
Istoric:
Primit 8 martie 2020
Acceptat 25 aprilie 2020
Publicat 10 iunie 2020
Cuvinte-cheie:
transfer lingvistic
interferență
învățarea unei limbi străine

\section{Despre articol}

Primit 8 martie 2020

Acceptat 25 aprilie 2020

Cuvinte-cheie: interferență învățarea unei limbi străine

\begin{abstract}
Rezumat
Pornind de la Lord (2008), care susține că „mulți cercetători studiază efectele L2 asupra limbii materne, dar puțini cercetători analizează efectele limbii materne asupra L2", am decis să analizez în această lucrare greșelile produse de studenții români atunci cînd traduc propoziții care vizează timpuri verbale din limba română în engleză, pentru a stabili dacă greșelile sînt produse sau nu ca urmare a transferului cunoștințelor gramaticale ale studenților din limba maternă în L2 sau, de ce nu, dacă greșelile apar ca rezultat al altor factori. Se afirmă adesea că, atunci cînd studenții transferă cunoștințe gramaticale din L1 în L2, pot apărea greșeli din cauza diferențelor structurale de gramatică dintre limba sursa și limba țintă. Din acest punct de vedere, diferenţe importante între sistemul verbal românesc și cel englez (aspectul, secvențialitatea temporală reflectată în raportul de posterioritate, simultaneitate și anterioritate) ar putea dezvălui în final faptul că studenții români care învață engleza ca limbă străină transferă în engleză structuri și forme din limba română, ceea ce duce inevitabil la greșeli. Atunci cînd analizează motivele care duc la apariția greșelilor în învățarea unei limbi străine, lingviștii, profesorii și metodologii susțin că interferența dintre limba maternă (româna, în acest caz) și limba nou-învăţată (engleza) este o sursă importantă de greșeli. Interferența lingvistică, cunoscută și sub denumirea de transfer lingvistic, se referă la transferul caracteristicilor lingvistice între limbi, subliniind faptul că transferul poate fi fie pozitiv, fie negativ. Transferul lingvistic pozitiv are loc atunci cînd structura sau elementul gramatical este același în ambele limbi și, în consecință, rezultatul este corect. Dimpotrivă, transferul lingvistic negativ are loc atunci cînd structura gramaticală este diferită de la o limbă la alta, iar rezultatul încalcă legile lingvistice în limba țintă. Abordarea teoretică care se ocupă de analiza diferențelor și asemănărilor dintre limbi este analiza contrastivă care a demonstrat că atunci cînd două limbi sînt distincte, probabilitatea unui transfer negativ mai mare este posibilă. Aceasta implică faptul că oricare două limbi care au reguli gramaticale asemănătoare ar avea ca rezultat un transfer pozitiv. Analiza contrastivă își dovedește utilitatea mai ales în procesul de predare-învățare; în primul rînd, profesorul trebuie să fie conștient de diferențele dintre prima limbă a studenților și L2 pentru a-i ajuta să depășească dificultățile atunci cînd învață o limbă străină și să reducă numărul de greșeli de transfer pe care studenții le pot face. În al doilea rînd, studenții trebuie să fie conștienți de aceste diferențe pentru a lua decizii lingvistice complet informate. Astfel, aceasta este o metodă predictivă de a cunoaște în prealabil ce ar putea duce la greșeli atunci cînd studenții români traduc din limba română în engleză. Cu toate acestea, predarea nu ar trebui să se bazeze pe această analiză comparativă ca singura modalitate de predare.
\end{abstract}

*Adresă de corespondență: cristina.valcea@unitbv.ro. 


\section{Scopul cercetării}

Am decis să analizez în această cercetare greșelile produse de studenții români în traducerea frazelor care vizează timpurile verbale din limba română în engleză, pentru a stabili dacă greșelile sînt produse sau nu ca urmare a transferului cunoștințelor gramaticale ale studenților din limba maternă în L2. Atunci cînd studenții transferă cunoștințe gramaticale din L1 în L2 pot apărea greșeli din cauza diferențelor structurale de gramatică dintre limba sursa și limba țintă. Din acest punct de vedere, diferențe importante între sistemul verbelor românești și engleze (aspectul, secvențialitatea temporală reflectată în posterioritate, simultaneitate și anterioritate) ar putea dezvălui în final că studenții români care învață engleza ca limbă străină transferă în engleză structuri și forme din limba română, ceea ce ar putea duce la greșeli.

\section{Stadiul actual al cercetării}

Învățarea unei limbi străine a fost analizată cu scopul descoperirii mecanismelor și instrumentelor care contribuie la învățarea unei limbi noi cu toate efectele secundare care resultă, cum ar fi interferența dintre L1 și L2 care ar putea rezulta, în funcție de compatibilitatea gramaticală dintre limbi, într-un transfer pozitiv sau negativ. Transferul lingvistic este pozitiv atunci cînd structura sau elementul gramatical este același în ambele limbi și, în consecință, rezultatul este corect. Dimpotrivă, transferul lingvistic negativ are loc atunci cînd structura gramaticală este diferită de la o limbă la alta, iar rezultatul încalcă legile lingvistice din limba țintă.

Termenul interferență a fost utilizat pentru prima dată în raport cu fenomenul bilingvismului de către Weinreich (1953, p. 1), care a definit interferența drept „acele cazuri de abatere de la normele oricărei limbi care apar în vorbirea bilingvilor ca urmare a familiarizării lor cu mai multe limbi”. Lado (1957, p. 1) evidențiază caracteristici definitorii ale interferenței cum ar fi dependența pronunțată de caracteristicile L1 atunci cînd L1 și L2 împărtășesc caracteristici comune: „Presupunem că studentul care vine în contact cu o limbă străină va considera unele caracteristici ale acesteia destul de ușoare, iar altele extrem de dificile. Acele elemente care sînt similare cu limba sa maternă vor fi simple pentru el, iar elementele care vor fi diferite vor fi dificile”. Mai mult decît atît, Lado (1957, p. 59) vine cu o teorie pe care o numește Ipoteza Analizei Contrastive (IAC), în care susține că dificultățile studentului cînd învață L2 pot fi ușor prezise printr-o „comparație propoziție-cu-propoziție” între L1 și L2-ul studentului. Cu alte cuvinte, cu cît limbile sînt mai diferite, cu atît este mai mare dificultatea de a învăţa orice L2. În mod similar, cu cît este mai mare asemănarea dintre L1 și L2, cu atît este mai mare probabilitatea de a învăța orice L2.

Școlile lingvistice au elaborat diferite teorii care să explice modul în care se învață limbile, cum are loc transferul și cum se produc greșelile, pe baza diverselor elemente care contribuie la învățare.

O astfel de abordare, cea comportamentală (Cooter \& Reutzel, 2004) susține că la baza învățării este imitația, ca o repetare simplă a unei structuri la care fusese expus anterior și pe care acum o poate reproduce, ceea ce îi ajută pe tinerii cursanți să învețe multe structuri noi prin reproducerea comportamentului verbal al adultului. Utilizatorul individual nu este perceput ca adaptîndu-și limbajului la propriile nevoi sau ca creator de sens; ei sînt practic imitatori care reproduc structurile limbii fără a o influenţa. Imitația este însoțită de recompense și exerciții pentru a stimula comportamentul lingvistic independent. Cu toate acestea, un neajuns al acestei abordări în ceea ce privește învățarea unei limbi străine este faptul că ea se aplică mai ales la învățarea limbii materne, ceea ce o face mai puțin potrivită învățării unei limbi străine.

Decurgînd din behaviorism, dar dezvoltîndu-se într-o direcție divergentă, se consideră că învățarea asociativă reprezintă „capacitatea organismelor vii de a percepe relațiile de contingență între evenimentele din mediul lor. Este o componentă fundamentală a comportamentului adaptativ, deoarece permite anticiparea unui eveniment pe baza altuia" (Jozefowiez, 2012, p. 17). Astfel, conform învățării asociative, învățarea oricărei L2 se poate face prin „corelații statistice între stimuli și / sau răspunsuri” (Schmidt, 2012, p. 85). Rezultă că învățarea în general este un fenomen complex care se bazează pe asocieri, asemănări, diferențe, predicții care ajută oamenii să definească fenomenele nu în mod izolat, ci în legătură cu alte elemente. 
În ceea ce privește învățarea L2, aplicînd aceleași principii, corelațiile, asemănările și diferențele dintre L1 și orice L2 joacă un rol important în procesul de învățare. O altă contribuție importantă la învățarea asociativă este cea emisă de Corder (1967, p. 165), care schimbă perspectiva asupra greșelilor pe care nu le mai consideră ca indicatori ale dificultăţilor studenților, ci ca un indiciu al dificultățiii, „încercările active ale unui student de a se dezvolta sistematic prin însușirea informațiilor” (Ellis, 1997, p. 187). Conceptul lui Corder de inter-limbaj ilustrează etapa intermediară cind studenții construiesc cunoștințe în L2 bazînduse pe L1 și în care toate achizițiile lingvistice sînt importante pentru studentul care experimentează cu două sisteme lingvistice, uneori independent, alteori în comun. O problemă importantă care ilustrează dificultățile cu care studenții se confruntă atunci cînd învață limba engleză este fenomenul redundanței (Ellis, 1998, p. 179). El dă exemplul sistemului verbal englez unde referința temporală este indicată în principal şi în primul rînd de adverbe temporale, dar nu numai. Astfel, indiciile adverbiale temporale, fiind introduse mai întîi, tind să eclipseze orice alte indicii care ar putea indica referința temporală a unui verb. În consecință, studenții care învață L2, instruiți să identifice adverbialele temporale, vor ignora orice alte indicii care ar putea contribui foarte mult la stabilirea timpului și a aspectului care trebuie utilizate în anumite situații.

Abordarea comunicativă a predării și învăţării limbilor străine are o perspectivă diferită, avînd în vedere că interacțiunea este mijlocul și scopul învățării unei limbi străine. Abordarea comunicativă încearcă să impună ideea că toate limbile străine trebuie învățate prin însăși noile limbi, ceea ce sugerează eliminarea totală a limbii materne, care este interpretată ca un obstacol în calea învăţării unei limbi străine. Cu toate acestea, Swan (1985, p. 85) critică eliminarea intenționată a L1 din învățarea L2, considerînd că este normal ca studenții să pornească de la presupunerea că atît L1 cît și L2 au elemente similare, ceea ce se va dovedi corect sau nu mai tîrziu în momentul în care ei aprofundează studiul L2: „De fapt, dacă nu am continua să facem corespondențe între cuvintele din limba străină și cele de limbă maternă, nu am învăța niciodată limbi străine.” Mai mult decît atît, el susține că L1 și interferența dintre L1 și L2 nu ar trebui să fie învinovățită pentru greșelile care ar putea apărea în procesul de învățare, deoarece, susține el, limba maternă este cea care garantează într-o mare măsură succesul în vorbirea corectă a oricărei L2: „Se știe foarte bine că inter-limbajele conțin greșeli cauzate de interferența limbii materne; nu se conștientizează întotdeauna că o mare parte din trăsăturile corecte dintr-un inter-limbaj conţin și un element din limba maternă" (Swan, 1985, p. 85). Mult mai tîrziu, Storch \& Wigglesworth (2003, p. 762) împărtășesc ideea lui Swan argumentînd că „utilizarea L1 poate oferi studenților un sprijin cognitiv suplimentar care le permite să analizeze limba și să lucreze la un nivel mai ridicat decît ar fi fost posibil dacă ar fi limitaţi la utilizarea exclusivă a L2". Yadav (2014) vine deasemenea în apărarea L1 care, consideră el, ar trebui percepută ca o resursă pe care studenții o folosesc în mod conștient sau inconștient pentru a organiza informaţia învăţată, astfel încît să poată produce structuri corecte.

În mod diferit, abordarea cognitivă (Achard \& Niemeier, 2004, p. 4) este foarte interesată de limbă așa cum este utilizată de vorbitori cu variațiile pe care le aduc și, în consecință, de dinamica limbii. Spre deosebire de abordarea behavioristă care se referă în mod predominant la învăţarea limbilor materne, abordarea cognitivă, mai cuprinzătoare în domeniul de aplicare, abordează învăţarea atît a limbilor materne, cît și a limbilor străine, concentrîndu-se pe asemănările și diferențele existente în învăţarea limbilor. În al doilea rînd, abordarea cognitivă oferă o explicaţie pentru marea varietate de structuri alternative care se regăsesc în limbă ca o oglindire a marii capacități de imaginație a vorbitorilor unei limbi de a reprezenta unul și acelaşi eveniment sau fapt (Langacker, 2008, p. 7).

Atunci cînd abordăm problema învățării unei limbi străine, abordarea cognitivă recunoaște concurența existentă între L1 și L2, deoarece vorbitorul va fi întotdeauna tentat să apeleze la L1 atunci cînd produce un discurs în L2. De fapt, Achard \& Niemeier (2004, p. 6) susţin că „într-un sistem L2 în dezvoltare, unitățile țintă sînt în concurență directă cu cele native, deoarece ambele reprezintă modalități alternative de a-şi imagina aceeași realitate.” Deși, aparent, lingvistica cognitivă admite ca firesc sprijinul pe care îl caută studenții în L1-ul lor atunci cînd se confruntă cu dificultățile L2, există destul de mulți profesori care consideră că este o greșeală. Aceștia susțin de fapt că cu cît studenții se bazează mai mult 
pe L1-ul lor, cu atît vor avea o dificultate crescută de a învăța L2 și, mai mult decît atît, cu atît va crește interferența dintre L1 și L2. Cu toate acestea, lingvistii cognitivi Achard \& Niemeier (2004) susțin că între L1 și L2 există un fenomen de transfer destul de activ din L1 în L2 și mai degrabă redus, deși posibil, din L2 în L1. Motivul pentru care L1 transferă informaţii gramaticale în L2 este „accesibilitatea şi gradul de automatism atins în L1" (Waara, 2004, p. 52) atunci cînd acest nivel este efectiv atins ca în cazul adulților.

O demonstrație a faptului că învățarea unei limbi nu este independentă de nicio altă limbă care a fost deja învățată este dovada existenței fenomenului de amestecare. Atunci cînd ambele limbi contribuie la discurs cu unele structuri cu care vorbitorul este familiarizat fie în L1, fie în L2, atunci, potrivit lui Fauconnier (1997), apare fenomenul de amestecare care desemnează un spațiu nou creat voluntar (vorbitorul cunoaște structurile distincte din ambele limbi, dar preferă să îmbine ambele limbi) sau involuntar (vorbitorul nu cunoaște structura într-una dintre limbi și o folosește pe cea cunoscută). Un exemplu de îmbinare între română și engleză care apare destul de frecvent în managementul corporativ românesc și care este o ilustrație a influenței L2 asupra L1, deoarece engleza este limba internațională a managementului corporatist în următorul fragment dintr-o conversație:

"Crezi că face sens să forcastăm în continuare pe pipeline-ul deja existent, în care customizăm produsele de end-user?” (Adevărul, 4 feb. 2015, de Ioana Nicolescu [online])

"Do you think it makes sense to continue forecasting on the existing pipeline, where we customize the end-user products?" (trad.n.)

Acest amestec între română și engleză folosită excesiv în corporații creează, după cum a spus Fauconnier, un nou spațiu „romgleza”, care este un amestec de cuvinte românești și engleze și unde cuvintele engleze dublează cuvintele pe care le are limba română și care s-ar potrivi foarte bine în context, dar, vorbitorii preferă să folosească ceva definit de gramatică drept barbarisme. Unele dintre cuvintele engleze se diferențiază de echivalentul românesc corect, deoarece intenționează să păstreze întreaga structură engleză. Așadar, dacă în engleză „to make sense” este o structură perfect corectă, în limba română ,a face sens” este o simplă traducere mot-à-mot al echivalentului englezesc, dar limba română are expresia verbală „a avea sens” care este echivalentul englezului "to make sense”. "Să forcastăm” este un barbarism inutil, care ar fi putut fi ușor înlocuit cu „să prognozăm”, care ar fi fost suficient pentru a acoperi sensul cuvîntului englez „a prognoza", care, deși mai puternic în ceea ce privește sensul pentru corporatistul român, are un echivalent perfect acceptabil în limba română. Conducta se referă de fapt la fluxul deja existent care are un echivalent în limba română în ,flux” "Customizăm” nu este decît un alt barbarism care nu aduce nicio nuanță nouă, diferită de cea română, la mesajul care consolidează faptul că produsele ar trebui să fie "personalizate” pentru client, pentru care, din nou, limba română are echivalentul „a personaliza”. Utilizatorul final este preferat în acest discurs corporativ, avînd în vedere publicul țintă care este înconjurat permanent de o română tehnicalizată, impregnată cu engleză care a fost încărcată cu cuvinte gratuite pe care limba română le are şi care ar putea acoperi perfect sensul. „Utilizatorul final” este echivalentul care ar satisface sensul intenționat al vorbitorului. În concluzie, acesta este un exemplu al faptului că transferul între limbi există și indică în același timp că transferul poate apărea ca o necesitate (atunci cînd vorbitorul folosește o structură în limba maternă deoarece echivalentul în L2 este necunoscut) sau ca fapt gratuit (cînd vorbitorul apelează la L2, de exemplu, deși L1 are mijloacele lingvistice de a exprima acelaşi concept).

Un alt element caracteristic abordării cognitive este faptul că ceea ce trebuie studiat nu este norma lingvistică și modul în care este respectată, ci modul în care vorbitorul își imaginează respectarea și aplicarea regulii, ceea ce, atunci cînd analizează grupuri importante de respondenți, ar putea indica modul în care utilizatorii se raportează la limbă, fie că este L1 sau L2. Astfel, Waara (2004, p. 53) a creat conceptul de „construcții ale cursanților”, care sînt construcții care sînt „ușor neconvenționale”. „Deși utilizarea nu duce la o întrerupere a comunicării între participanți, ea se abate într-un fel.” Relevanța conceptului de "construcții ale cursanților” pentru transferul dintre L1 și L2 constă în faptul că studenții L2 produc structuri L2 în care este posibil să nu respecte complet regulile L2. Aceștia ar putea în egală măsură să 
folosească regulile L1 care se dovedesc mai la îndemînă şi mai cunoscute de către student. Cu toate acestea, mesajul lor în L2 este transmis în ciuda inadecvării contextuale sau a greșelilor gramaticale care pot apărea.

Alți cercetători au încercat să identifice elementele care îngreunează învățarea L2, pe de o parte și care pot crea interferențe, pe de altă parte. Astfel, Larsen-Freeman (1976, p. 128) susține că ordinea învăţării functorilor gramaticali este un element care poate crea interferențe între L1 și L2, avînd în vedere că aceștia sînt lipsiți de sens lexical și pot avea forme similare care îi vor confuza pe studenți. De exemplu, functorul „" este un marker pentru plural, la fel ca în $d o g$ - dogs, el este, de asemenea, un marker pentru persoana a treia singular ca în el/ea draws și marchează în egală măsură genitivul sintetic în engleză ca în butcher's house. Toate aceste situații pot pune probleme studenților care învață engleza și, prin urmare, ei pot utiliza cunoștințele din limba maternă ca suport pentru alegerile gramaticale dificile pe care le au de făcut. Acest lucru coroborat cu ideea lui Matessa \& Anderson (2000, p. 273), conform căreia începătorii învaţă L2, concentrîndu-se pe „un indiciu” pe rînd, arată că învățarea oricărei L2 este un proces dificil, care presupune o expunere treptată la indicii, ceea ce va conduce, în final, la o reducere a greșelilor care apar din cauza neînțelegerilor sau a transferului.

\section{Transferul lingvistic în traduceri}

În scris sau vorbire, L1, mai bine echipat și mai uşor de utilizat, va transfera elemente lingvistice în L2, ceea ce va duce la greșeli. Cu toate acestea, transferul lingvistic are loc în traducere deoarece traducerea presupune redarea sensului unui text din L1 în L2. Cu toate acestea, sensul este exprimat prin vocabular, morfologie, sintaxă, pragmatică care se poate întîmpla să difere mai mult sau mai puțin între L1 și L2, ceea ce înseamnă că, uneori, structuri echivalente sau aproximări sînt utilizate pentru elementele care lipsesc în oricare dintre limbi. Havlaskova (2010) descrie interferența în traducere drept „un fenomen care poate apărea la nivelul unui cuvînt, al unei expresii, al unei metafore sau al unui component al unei structuri sintactice întregi atunci cînd traducătorii transferă unele texte sursă în texte țintă influențate de aspecte ale limbii sursă ". Benson (2002, p. 69) susține că astfel de transferuri se pot întîmpla la nivelul sintaxei ca în cazul unei traduceri cuvînt cu cuvînt și eșecul de a folosi correct concordanța timpurilor, la nivel lexical ca în caz cuvintelor fals-înrudite precum și în morfologie unde diferite aspecte din morfologia L1 vor fi transferate în L2 (absența subiectului, nerecunoașterea aspectelor). Mai mult decît atît, Benson (2002, p. 70) susține că traducerea atît a „propozițiilor” cît și a „textelor întregi” ar trebui încurajată, deoarece ilustrează „puncte specifice” și anticipează „anumite greșeli de transfer”.

\subsection{Scopul cercetării}

Pentru a verifica interferența dintre L1 (româna în acest caz) și L2 (engleza), am selectat o serie de propoziții care conțin suficiente diferențe, atunci cînd sînt comparate, astfel încît studenții să transfere cunoștințele de limbă din L1 în L2. Confirmarea interferenței dintre română și engleză în acest caz particular ar confirma, pe de o parte, teoria deja cunoscută a interferenței lingvistice, iar, pe de altă parte, ar reprezenta un motiv suplimentar pentru a încuraja profesorii să predea L2 prin compararea cu L1, pentru a relua lucrul la exerciții de traducere care au fost abandonate în mare parte odată cu apariția abordării comunicative a predării. În al treilea rînd, profesorii, avînd în vedere experiența lor, ar trebui să prezică elementele care pot interfera în L2 și ar trebui să fie pregătiți să le explice studenților elementele care declanșează greșelile de inferență pe care le-au făcut. Clarificarea greșelilor ar ajuta studenții să înțeleagă limbile ca organisme funcționale și învăţatul să fie o întreprindere continuă în care cunoștințele, atunci cînd sînt puține în L2, să se bazeze pe mecanismele L1 pentru a găsi o soluţie.

Activitatea pe care trebuiau să o susţină studenții a constat dintr-un număr de șase fraze pe care studenţilor li s-a cerut să le traducă. Frazele nu erau lungi, erau scurte şi simple, întrucît vizau anumite elemente lingvistice (morfologice, sintactice sau lexicale) care ar putea conduce la un transfer negativ sau pozitiv între română și engleză. În mod evident, propozițiile conțineau elemente care erau diferite în limba română față de engleză și se presupune că studenții ar putea greși prin utilizarea cunoștințelor lor de română atunci cînd traduc în engleză. 


\subsection{Participanții la studiu}

Studenții care participă la această cercetare sînt studenți la inginerie din anul I, care au ales limba engleză drept limba străină, fără niciun test formal de engleză dat la admitere. Sînt un grup eterogen cu abilităţi și niveluri de limbă mixte, de la începători pînă la utilizatori avansaţi de engleză. Studenții au participat voluntar la această cercetare. Cei care nu au dorit să participe la cercetare au lucrat pe același material, dar lucrările lor nu au fost colectate pentru analiză.

\subsection{Interferența morfologică}

Traducerile studenților au creat o serie de situații care au fost intuite anterior de profesor. $\mathrm{O}$ astfel de situație este reprezentată de construcțiile impersonale în limba română, care nu au subiect, deoarece este posibil în limba română să folosească un predicat fără subiect din cauza terminațiilor verbale personale. Dar această caracteristică este absentă în limba engleză, unde absența terminațiilor a dus la o prezență obligatorie a subiectului, pe care unii dintre studenți au ignorat-o complet. În mod surprinzător, aceeași situație se întîmplă în cazul verbului personal din aceeași propoziție care, din același motiv, nu are un subiect prezent în propoziţie.

(1) [subiect inexistent în limba română, expresie verbală impersonală $] \emptyset N u$ este politicos să te uiți la oameni cînd (2) [subiect absent în limba română, subiectul poate fi dedus de fapt din inflexiunile verbale] Ø mănîncă.

\begin{abstract}
Absența subiectului în (1) și (2) în română este păstrată în limba engleză, deoarece studenții nu își dau seama că ar trebui să utilizeze regulile morfologice engleze la traducerea în engleză.

* (1) Is not polite to look at people when (2) eat.

$\sqrt{ }(1)$ It is not polite to look at people when (2) they eat.
\end{abstract}

O altă greșeală apărută în traducerile elevilor este legată de sistemele verbale din limba română și engleză. În primul rînd, nu există o corespondență unu-la-unu între timpurile verbale românești și engleze și, în plus, acestea nu se referă la aceleași situații, ceea ce pune o presiune suplimentară asupra studenților români. În al doilea rînd, deși adverbele semnalează momentul acțiunii în limba română, nu adverbul este cel care impune selecția unuia sau altui timp verbal sau aspect. În limba română, adverbele dublează informațiile temporale conținute de verb, în timp ce în engleză, adverbul, în cele mai multe cazuri, solicită un anumit timp verbal. Frazele în acest caz au fost selectate astfel încît să testeze exact diferențele menționate mai sus și răspunsurile studenților la acestea.

În limba română, există un singur timp verbal prezent, întrucît limba română nu face distincția între o situație permanentă, una care are loc în momentul vorbirii sau o acțiune care a avut loc recent. Pentru toate aceste situații, limba română nu are decît un prezent. Spațiul intermediar dintre prezent și trecut le este complet necunoscut studenților români care se pot confrunta cu dificultăți, deoarece trebuie să folosească Prezentul Perfect pentru două timpuri verbale diferite în limba română, ca în ,își face bagajele" (has been packing) din cauza structurii ,since this morning” și „n-a terminat" (hasn't finished) din cauza lui ,yet”.
În engleză, în principal adverbul, deși nu se limitează la el, este cel care dictează alegerea atît a timpului, cît și a aspectului. Aspectul este categoria gramaticală care stabilește dacă acțiunea este terminată sau în curs de desfășurare, deoarece aceasta contribuie major la înțelegerea completă a acțiunii. Cînd traduc în engleză, studenții români nu reușesc să identifice timpul întrucît nu există în limba română, dar unii dintre ei reușesc să identifice aspectul continuu. Le scapă în întregime contribuția decisivă a adverbelor ,since this morning”, "yet” la selectarea timpului și stabilesc o echivalență între sistemul verbal românesc și cel englez. 
Sora mea își face bagajele (1) [este o expresie verbală reflexivă prezentă] de azi dimineață (2) [prezența adverbului nu schimbă timpul verbal care trebuie folosit, întărește doar valoarea prezentă a verbului], dar încă $n$-a terminat (3) [deși în limba română, forma verbului indică o acțiune finalizată, în engleză, mulțumită lui „încă”, Prezentul Perfect este preferat.]
* e.g. My sister is packing since this morning and she didn't finish yet $\sqrt{ }$ e.g. My sister has been packing since this morning and she hasn't finished yet

Deși limba română are noțiunea gramaticală de aspect, în principiu, ea încapsulează conceptele de [acțiune neterminată / în curs de desfășurare], ca în cazul „Imperfect”, de exemplu, dansa (s/he was dancing), vorbea (s/he was talking), minca (s/he was eating), [terminat] ca în cazul "perfectului compus", de exemplu, a dansat (s/he danced), a vorbit (s/he talked), a mîncat (s/he ate) și [terminat înainte de o altă acțiune] ca în "mai mult ca perfectul”, de exemplu, dansase ( $\mathrm{s} / \mathrm{h}$ had danced), vorbise (s/he had talked), mincase ( $\mathrm{s} / \mathrm{he}$ had eaten). Cu toate acestea, în engleză aspectele sînt mult mai complexe decît aceasta și acesta este exact locul unde este posibil să apară greșeli, deoarece limba română nu acoperă toate situațiile pe care le acoperă engleza.

Limba română nu face distincția între un prezent instantaneu şi un prezent permanent aşa cum o face engleza. De aceea, atunci cînd se confruntă cu o astfel de situație, studenții români pot face greșeli.

e.g. Bărbatul care (1) vorbește [prezent instantaneu] cu soția mea este vecinul nostru care (2) locuiește [prezent permanent] alături.
Lipsa distincției dintre [instantaneu] și [permanent] ar duce la greșeli în traducerea celei de-a treia acțiuni care se referă la o stare permanentă pe care studenții români ar traduce-o ca stare instantanee.

* The man who is talking to my wife is our neighbour who is living next door.

$\sqrt{ }$ The man who is talking to my wife is our neighbour who lives next door.

\subsection{Interferența sintactică}

În ceea ce privește sintaxa, există multe diferențe între română și engleză, dar există una care îi pune în dificultate în mod deosebit pe studenții români și care este concordanța timpurilor. Această regulă indică faptul că verbul din propoziția principală stabilește timpii de referință și că toate timpurile ulterioare, cum ar fi timpurile evenimentelor, se stabilesc în funcție de timpul verbului din propoziția principală. Întrucît nu există o asemenea restricție în limba română, studenților români le este greu să se familiarizeze cu conceptele de simultaneitate, anterioritate și posterioritate și cu aplicarea lor. Avînd în vedere că româna acceptă viitorul după trecut, studenții români vor tinde să folosească ceea ce acceptă limba română. O altă sursă de greșeli cu care se confruntă studenții români este faptul că anterioritatea nu este întotdeauna clar marcată, ceea ce îi face pe studenți să creadă că cele două acțiuni sînt simultane.

Existența celor două verbe avînd aceeași formă „ne-am mutat” și ,am locuit” este interpretată greșit ca fiind simultane și Past Tense Simple este folosit pentru a traduce verbele. Anterioritatea acțiunii de a trăi timp de zece ani într-o casă prin raportare la săptămîna trecută este complet ignorată.

Săptămîna trecută (1) ne-am mutat [acțiune trecută finalizată] din casa în care (2) [acțiune trecută finalizată] am locuit 10 ani.
Absența conceptelor în gramatica limbilor materne și traducerea frazei fără nicio încercare de a folosi regulile oricărei L2 care este învăţată este un indicator semnificativ al interferenței dintre L1 și L2.

${ }^{*}$ Last week we moved from the house where we lived for 10 years.

$\sqrt{ }$ Last week we moved from the house where we had lived for 10 years. 


\subsection{Interferența lexicală}

„Prietenii falşis”, așa cum sînt definiți în Dicționarul Cambridge, „sînt cuvinte care sînt adesea confundate cu alte cuvinte din alte limbi, cu semnificații diferite, deoarece arată sau par similare”. Studenții se bazează foarte mult pe cuvinte care arată ca niște cuvinte native, ceea ce le-ar conferi o gamă mai largă de vocabular atunci cînd au nevoie. Studenții români nu fac excepție și folosesc verbul englez „to declare” pentru cuvîntul român ,a declara”.

Propoziția „Vă declar soț și soție” este o formulă folosită ori de cîte ori un nou cuplu se căsătorește. Traducerea lui „a declara” prin „to declare", care se deosebește de primul prin numai o literă, este o capcană obișnuită pentru studenții care nu folosesc frecvent limba engleză și nu au un interes special în învățarea ei.
Dicționarul Cambridge definește „to declare” ca „a anunța ceva clar, ferm, public sau oficial”, care este diferit de formula ceremonială engleză care este folosită în mod tradiţional la căsătorie „I pronounce you man and wife”. Mai mult, studenţii copiază modelul românesc și traduc „soț şi soție” ca „husband and wife”, care diferă de sintagma folosită în engleză „man and wife”.

\section{Soluţii pentru transferul lingvistic}

Transferul lingvistic a fost învinovățit pentru multe tipuri de greșeli pe care studenții L2 le fac ca urmare a diferențelor fonetice, lexicale, morfologice, sintactice și pragmatice între L1 și L2. Studenții își transformă limba maternă într-un punct de referință față de care imputul din L2 este comparat. Orice greșeală care rezultă de aici reflectă nevoia cursanților de a se baza pe ceva sigur atunci cînd învață ceva nou sau dificil.

Deoarece transferul lingvistic a fost considerat „natural” de către lingviști, atunci profesorii ar trebui să țină seama de existența sa în procesul de predare și să profite de acesta dacă există compatibilități între limbile L1 și L2 (Pavel, 2019, p. 6029). Studenții ar trebui informați despre compatibilitatea sau lipsa acesteia între L1 și L2 prin intermediul unei analize contrastive care ar trebui să fie încorporată în procesul de predare/ învățare, deoarece studenții ar trebui să fie conștienți de asemănările și diferențele dintre limbi, ca un factor care poate contribui fie la învățarea corectă a L2, fie la probabilitatea lor de a greși în L2 din cauza diferențelor dintre L1 și L2. Prin urmare, profesorii ar trebui să sublinieze caracteristicile proprii fiecărei limbi și să crească gradul de conștientizare al studenților cu privire la caracteristicile specifice limbii care pot crea dificultăți atunci cînd traduc din L1 în L2. Mai mult, profesorii ar trebui să-i implice pe studenți în identificarea situațiilor de transfer prin conceperea unor contexte în care studenții trebuie să facă distincția între alegerea corectă/ greșită care poate rezulta din transferuri pozitive sau negative. Sau, profesorii le-ar putea cere studenților să creeze contexte în care să folosească situații de transfer pozitive sau negative, deoarece, în acest fel, elevii arată o înțelegere a fenomenului și pot vedea exact cum funcționează transferul.

\section{Concluzii}

Scopul acestei cercetări a fost să verifice existența interferenței lingvistice dintre L1 și L2 (engleză) a elevilor români atunci cînd lucrează la traducerea unor fraze din limba română în engleză. Frazele au fost alese în mod intenționat, astfel încît să conțină diferențe flagrante între română și engleză pentru a verifica dacă studenții români participanți la studiu vor transfera structurile românești din limba română în engleză sau, dimpotrivă, vor folosi structurile engleze. Transferul structurilor românești în limba engleză va demonstra că studenții participanți la cercetare nu au fost utilizatori independenți de engleză capabili să aplice în mod conștient structurile engleze. Dimpotrivă, absența sau transferul redus între L1 și L2 ar indica faptul că transferul nu are loc deoarece studenții participanți au atins un nivel de stăpînire a limbii engleze care le permite să se bazeze doar pe structurile engleze. În legătură cu aceasta, cercetarea a demonstrat că acești 
participanți se bazează foarte mult pe limba română atunci cînd traduc în engleză ceea ce înseamnă că atunci cind se ocupă de engleză ei nu s-au desprins de limba română pe care o folosesc ca suport important.

În al doilea rînd, orice transfer lingvistic este un mod normal de a trata noi informații, ceea ce poate fi o explicație a motivului pentru care studenții trebuie să se bazeze pe ceva cu care sînt foarte familiari. Ar trebui înțeles ca un mecanism de protecție, deoarece învățarea înseamnă adaptarea regulilor la propria înțelegere a limbii, prelucrarea noilor informații și exersarea cu mai mult sau mai puțin succes. Cînd transferul dintre L1 și L2 este pozitiv, consecința este un proces ușor de învățare care are ca rezultat învățarea. Cînd transferul dintre L1 și L2 este negativ, consecința este un proces dificil de învățare care poate duce la greșeli care necesită clarificări suplimentare.

În al treilea rînd, exerciţiile de traducere sînt activităţi complexe care ar putea cauza numeroase transferuri de structuri între L1 și L2. Deși traducerile au fost descurajate, poate pentru că Abordarea Comunicativă a încercat să evite exact dificultățile care apar din cauza diferențelor dintre L1 și L2, traducerile măresc, consider, conștientizarea studentului asupra caracteristicilor lingvistice ale fiecărei limbi, care ar putea ajuta la formarea de vorbitori informați de limbi străine în loc de vorbitori care evită necazurile de a descoperi că limbile diferă și că diferența stimulează învăţarea.

În cele din urmă, nu este recomandat să le spui studenților să înceteze să se bazeze pe L1-ul lor, deoarece ei nu vor renunța la singura resursă disponibilă. Mai mult, este rolul cadrelor didactice să prevadă ceea ce ar putea duce la transfer negativ și să încerce să instruiască studenții cum să le facă față. Cu toate acestea, transferul pozitiv este extrem de valoros şi ar trebui să fie exploatat în mod conștient atît de profesor, cît și de studenți, deoarece sporește interesul, motivația și progresul studenților.

\section{Bibliografie}

Achard, M. \& Niemeier, S. (2004). Cognitive Linguistics, Second Language Acquisition, and Foreign Language, Mouton de Gruyter, Berlin, Crossref.

Benson, C. (2002). Transfer/Cross-linguistic influence. Key concepts in ELT, Oxford University Press, Oxford.

Cooter, R.B. \& Reutzel, D.R. (2004). Teaching children to read: Putting the pieces together, Pearson Education, Inc., Upper Sadle River, NJ.

Corder, S.P. (1967). The significance of learners'errors, în „International Review of Applied Linguistics”, 5 (1-4), p. 161-169, Crossref.

Ellis, R. (1997). The Study of Second Language Acquisition, Oxford University Press, Oxford.

Ellis, R. (1998). Second Language Acquisition, Oxford University Press, Oxford.

Fauconnier, G. (1997). Mappings in Thought and Language, Cambridge University Press, Cambridge, Crossref.

Havlaskova, Z. (2010). Interference in students' translation, Masaryk University, Brno.

Jozefowiez J. (2012). Associative Learning, în Seel, N. M. (ed.), Encyclopedia of the Sciences of Learning, Springer, Boston, MA, Crossref.

Lado, R. (1957). Linguistics across Cultures: Applied Linguistics for Language Teachers, University of Michigan Press, Ann Arbor.

Langacker, R. (2008). The relevance of Cognitive Grammar for language pedagogy, în de Knop, S. \& de Rycker, T. (eds), Cognitive Approaches to Pedagogical Grammar, Mouton de Gruyter, Berlin.

Larsen-Freeman, D. (1976). An Explanation for the Morpheme Acquisition Order of Second Language Learners, în „Language Learning", 26 (1), p. 125-134, Crossref.

Lord, G. (2008). Second language acquisition and first languagephonological modification, în Bruhn de Garavito, J. \& Valenzuela, E. (eds), Proceedings of the 10th Hispanic linguistics symposium, Cascadilla proceedings project, Somerville, MA, p. 184-193, [online].

Matessa, M. \& Anderson, J.R. (2000). Modellingfocused learning in role assignment, în „Language and Cognitive Processes”, 15 (3), p. 263-292, Crossref.

Pavel, E. (2019). English for Medical Purposes: From Errors to Alternative Pedagogical Solutions, în „ICERI2019 Proceedings”, p. 6029-6035, Crossref.

Schmidt, J.R. (2012). Human Contingency Learning, în Seel, N.M. (ed.), Encyclopedia of the Sciences of Learning, Springer, Boston, MA, Crossref.

Storch N. \& Wigglesworth, G. (2003). Is there a Role for the Use of the L1 in an L2 Setting?, în „TESOL Quarterly”, 37 (4), p. 760-770, Crossref.

Swan, M. (1985). A critical look at the Communicative Approach (2), în „ELT Journal”, 39 (2), p. 76-87, Crossref. 
Waara, R. (2004). Construal, Convention and Constructions in L2 Speech, în Achard, M. \& Niemeier, S. (eds), Cognitive Linguistics, Second Language Acquisition, and Foreign Language, Mouton de Gruyter, Berlin, p. 51-76, Crossref.

Weinreich, U. (1953). Languages in contact, Linguistic Circle of New York, New York.

Yadav, M. (2014). The Role of Mother Tongue in Second Language Learning, în „International Journal of Research”, 1 (11), p. 572-582, [online]. 